\title{
Tablet alebo notebook? Komparatívna štúdia žiakovho vnímania rozdielnych technologických prístupov $v$ počítačom podporovanom chemickom laboratóriu
}

\author{
Tablet or Notebook? A Comparative study of Student's Perception of Different \\ Technological Approaches in Computer Supported Chemistry Labs
}

\author{
Marek Skoršepa ${ }^{1, *}$, Jarmila Kmet’ová ${ }^{1}$, Erika Horváthová ${ }^{1}$ \\ ${ }^{1}$ Univerzita M. Bela, Fakulta prírodných vied, Tajovského 40, 97401 Banská Bystrica, Slovensko; marek.skorsepa@umb.sk
}

Školské experimentovanie s podporou výpočtovej techniky je v relevantnej literatúre už niekolko desiatok rokov prezentované ako jeden zo slubných prístupov v štúdiu prírodných vied. Technológie však podliehajú velmi častým a rýchlym zmenám, a preto aj v oblasti počítačovej podpory laboratórnej činnosti žiakov možno za posledné obdobie sledovat rôzne technologické riešenia. V tomto príspevku sa zaoberáme komparáciou žiakovho vnímania experimentovania s meracími systémami s dvomi rozdielnymi koncovými zariadeniami: (i) notebookmi a (ii) tabletmi. Pre účely štúdie sme vytvorili sadu štyroch počítačom podporovaných aktivít z chémie, ktoré boli realizované dvomi skupinami žiakov slovenských gymnázií. Kým prvá skupina žiakov pracovala $\mathrm{s}$ meracím systémom pripojeným $\mathrm{k}$ notebooku, druhá skupina pracovala na rovnakých aktivitách, s tým istým meracím systémom pripojeným $\mathrm{k}$ tabletu. Cielom štúdie je zistit, či rozdielne technologické prístupy majú potenciál generovat štatisticky významné rozdiely vo vnímaní tohto typu experimentovania samotnými žiakmi.

Klíčová slova:
vyučovanie chémie,
počítačom podporované
laboratórium, počítačový
merací systém,
notebook, tablet.

Zasláno 3/2019

Revidováno $12 / 2019$

Prijato $1 / 2020$
School experimenting assisted by computer devices has been reported as one of promising ways of learning science for a couple of decades. However, technology has been changing very often and quickly. This is why many technological approaches can be seen in the field of computer assisted laboratory work over the years. This paper deals with the comparison of student's perception of experimenting with measuring systems using two different computer terminals: (i) notebooks and (ii) tablets. For the purpose of the study we designed a set of four computer-based laboratory activities for chemistry to be performed by two cohorts of Slovak grammar school students. While working on the same activities and with the same measuring system, one cohort operated measuring systems connected to notebooks and the other one operated measuring systems connected to tablets. The goal of the study is to find out whether different technological approaches are able to generate significant differences in students' perceptions of such a type of experimenting.

Key words:
chemistry education,
computer based
laboratory, computer
measuring system,
notebook, tablet.

Received 3/2019

Revised 12/2019

Accepted 1/2020

\section{1 Úvod}

Chémia je žiakmi často vnímaná ako príliš náročný predmet, predovšetkým pre velký počet abstraktných tém, ktoré sú jej súčastou. Učitelia tak stoja pred nelahkou úlohou, ako zvýšit záujem žiakov a prekonat niekolko bariér na ceste $\mathrm{k}$ efektívnej výučbe tohto predmetu. Vel'kú pomoc vo vyučovaní chémie zabezpečuje práve experimentálna činnost' (Hofstein, 2004; Mamlok-Naaman et al., 2018), ktorá pomáha prepojit abstraktné témy s realitou chemických dejov. Laboratórne práce žiakov nielen motivujú, ale aj výrazne prispievajú k porozumeniu prezentovaného obsahu (Gilbert \& Treagust, 2009; Johnstone, 2010). Z tohto dôvodu je pozornost mnohých výskumov zameraná práve na rozvoj, ale aj účinnost experimentálnej činnosti žiakov.

V dnešnej dobe technológií sa vo vyučovaní čoraz viac využíva rozličná počítačová technika, ktorá sa prirodzene dostala aj do školských chemických (resp. prírodovedných) laboratórií. Vytvorilo sa tým technické zázemie na prepojenie rôznych digitálnych zariadení so samotnými meracími prístrojmi, čo umožňuje merané dáta zaznamenávat̉, zobrazovat’ a vyhodnocovat’ v digitálnej podobe. Vzhladom na súčasnú technologickú variabilitu, ktorá sa v oblasti školského počítačom podporovaného experimentovania prejavuje najmä v existencii širokej škály rozličných koncových zariadení počítačových meracích systémov (Skoršepa, 2015), sa vynára otázka, či rôzne technologické prístupy použité na podporu prírodovedného experimentovania môžu ovplyvňovat̉ proces realizácie a samotnú efektivitu vyučovania.

Hoci v priebehu takmer štyridsatročnej (v zahraničí) existencie počítačom podporovaného experimentovania vo výchovnovzdelávacom prostredí bolo realizovaných obrovské množstvo výskumov skúmajúcich rozličné aspekty tohto prístupu, štúdie uvažujúce o type použitého technologického riešenia ako o možnom faktore generujúcom potenciálne rozdiely vo vnímaní experimentovania samotnými žiakmi, sa začali 
objavovat až v posledných rokoch (Priest et al., 2014). V našej štúdii sme adaptovali publikované postupy na porovnanie žiakovho vnímania počítačom podporovaného experimentovania ovládaného notebookom a dotykovým zariadením - tabletom v slovenských podmienkach.

\section{Počítačové meracie systémy $\mathbf{v}$ školskom prírodovednom laboratóriu - prehlad výskumov}

Experimentovanie s meracími systémami sa v literatúre najčastejšie označuje termínom Microcomputer Based Laboratory $(M B L)$ (Tinker, 1984, 2000; Tortosa Moreno, 2012), ktorý pochádza ešte z osemdesiatych rokov minulého storočia. Hoci dnes už nevystihuje situáciu úplne presne, najmä kvôli neaktuálnemu pojmu microcomputer - mikropočítač (Skoršepa, 2015), čo je aj hlavným dôvodom na jeho odmietanie, so skratkou MBL sa stále stretávame aj v nedávnych (najmä zahraničných) publikáciách (Pierri et al., 2008; Voogt et al., 2009; Aksela, 2011; Tho \& Hussain, 2011; Tortosa Moreno, 2012; Urban-Woldron et al., 2013; Rane, 2013; Priest et al., 2014). Medzi frekventované novšie pojmy patrí datalogging (Lavonen et al., 2003), označujúci prácu so senzormi pripojenými $\mathrm{k}$ dataloggeru a probeware (Kovalchick \& Dawson, 2004; Linn \& Eylon, 2011), v užšom význame označujúci hardvérovú čast meracieho systému zahŕňajúcu jednotlivé senzory a ich sondy ( $\mathrm{z}$ angl. probe = sonda, snímač), v širšom význame označujúci celý technologický prístup, podobne ako MBL.

Odhliadnuc od terminologickej nejednotnosti prameniacej najmä z existencie rôznych technologických variantov toho istého experimentálneho riešenia je dôležité, že dostupné štúdie potvrdzujú mnohé pozitívne črty tohto spôsobu školského experimentovania. Z niektorých výskumov realizovaných po roku 2000, najmä tých, ktoré presadzujú konštruktivistické prístupy vo vzdelávaní, vyplynuli odporúčania na posilnenie školskej laboratórnej praxe práve implementáciou počítačových meracích systémov (Borghi et al., 2001; Bernhard, 2003; Russell et al., 2003; Ambrose, 2004; Sassi et al., 2005). Vychádzali pritom zo starších výskumov, ktoré jednoznačne preukázali pozitívny efekt aplikovania počítačových meracích systémov do experimentálnej činnosti žiakov, a to v rozličných pedagogických a pedagogicko-psychologických aspektoch (Tinker, 1984; Linn \& Songer, 1991; Thornton, 1991). Mnohí renomovaní odborníci sa už na prelome tisícročí domnievali, že nesporná výhoda tejto počítačovej podpory oproti tradičnému experimentovaniu (bez počítačových meracích systémov) sa prejavuje najmä pri získavaní (zbere) experimentálnych dát a ich vizualizácii (Redish et al., 1997; Euler \& Müller, 1999; Svec, 1999; Marcum-Dietrich, 2002; Russell et al., 2003). Pritom za najvýznamnejší benefit tohto spôsobu experimentovania je považovaná tzv. simultánna grafická reprezentácia meraných závislostí v reálnom čase, ktorá výrazne prispieva k zvýšeniu schopností žiakov správne „čítat" a interpretovat grafy (Brasell, 1987a, 1987b; Beichner, 1990; Barton, 1997; Testa et al., 2002), a zároveň pomáha prirodzene prepojit konkrétnu zložku makroskopického pozorovania s jeho abstraktnou reprezentáciou (Mokros \& Tinker, 1987; Thornton \& Sokoloff, 1990; Trumper \& Gelbman, 2001). Navyše, niektoré štúdie zaznamenali vyšší stupeň aktívneho zapojenia žiakov v procese vytvárania si logických vzt̉ahov vedúcich k pochopeniu riešenej problematiky (Linn et al., 1987; Rogers, 1995). Vysvetlujú to intenzívnejšou orientáciou na interpretáciu výsledkov a nie na zaznamenávanie dát (Linn \& Hsi, 2000).

Širokým spektrom rôznych aspektov počítačovej podpory experimentovania v prírodovednom vzdelávaní sa od polovice devätdesiatych rokov minulého storočia zaoberajú aj českí a slovenskí autori, napríklad v prácach (po roku 2000): Šmejkal a Stratilová Urválková (2011, 2012), Bílek, Kričfaluši a Budweiserová (2002), Schauer, Lustig, Dvořák a Ožvoldová (2008), Skoršepa (2012, 2014, 2015), Gašparík (2014), Ješková (2004), Zelenický, Valovičová, Jenisová a Štubňa (2011).

Za posledných tridsat rokov, odkedy sa v pedagogickom prostredí objavili prvé aplikácie počítačových zariadení do experimentovania v prírodovedných predmetoch, sa však mnoho zmenilo aj v oblasti technológii použitelných na tento účel. Od prvých počítačov (resp. mikropočítačov) a kalkulačiek, ku ktorým sa v osemdesiatych rokoch pripájali meracie senzory a sondy (Nachmias \& Linn, 1987; Stein, 1987; Thornton, 1991), sme sa posunuli k výkonnejším, prenosnejším a inteligentnejším zariadeniam: notebookom, dataloggerom, tabletom a smartfónom. Prehlad rozličných technologických spôsobov usporiadania meracieho systému pri použití rôznych koncových počítačových zariadení uvádzame na obr. 1 . Aj ked väčšinu z týchto koncových zariadení nenazývame počitačmi, v skutočnosti ich tiež možno chápat ako špeciálne počitačové prístroje so špecifickými funkciami, ktoré štandardný počítač v istých ohladoch zastupujú. To je tiež dôvod, prečo sa komunita autorov pôsobiacich $\mathrm{v}$ tejto oblasti zatial nevzdáva pojmov počítačom podporované laboratórium, počítačom podporované experimentovanie, počítačový merací systém a pod.

Je tiež potrebné si uvedomit, že dnes je používanie týchto zariadení pre väčšinu žiakov bežnou súčastou ich každodenného života, a preto je ich implementácia do vyučovania prirodzenejšia ako v minulosti. Pritom nesmieme zabúdat ani na skutočnoste, že práca s nimi nielen ulahčuje žiakom určité fázy experimentovania, čím im umožňuje koncentrovať sa na podstatu samotného experimentu, ale ako ukazujú 


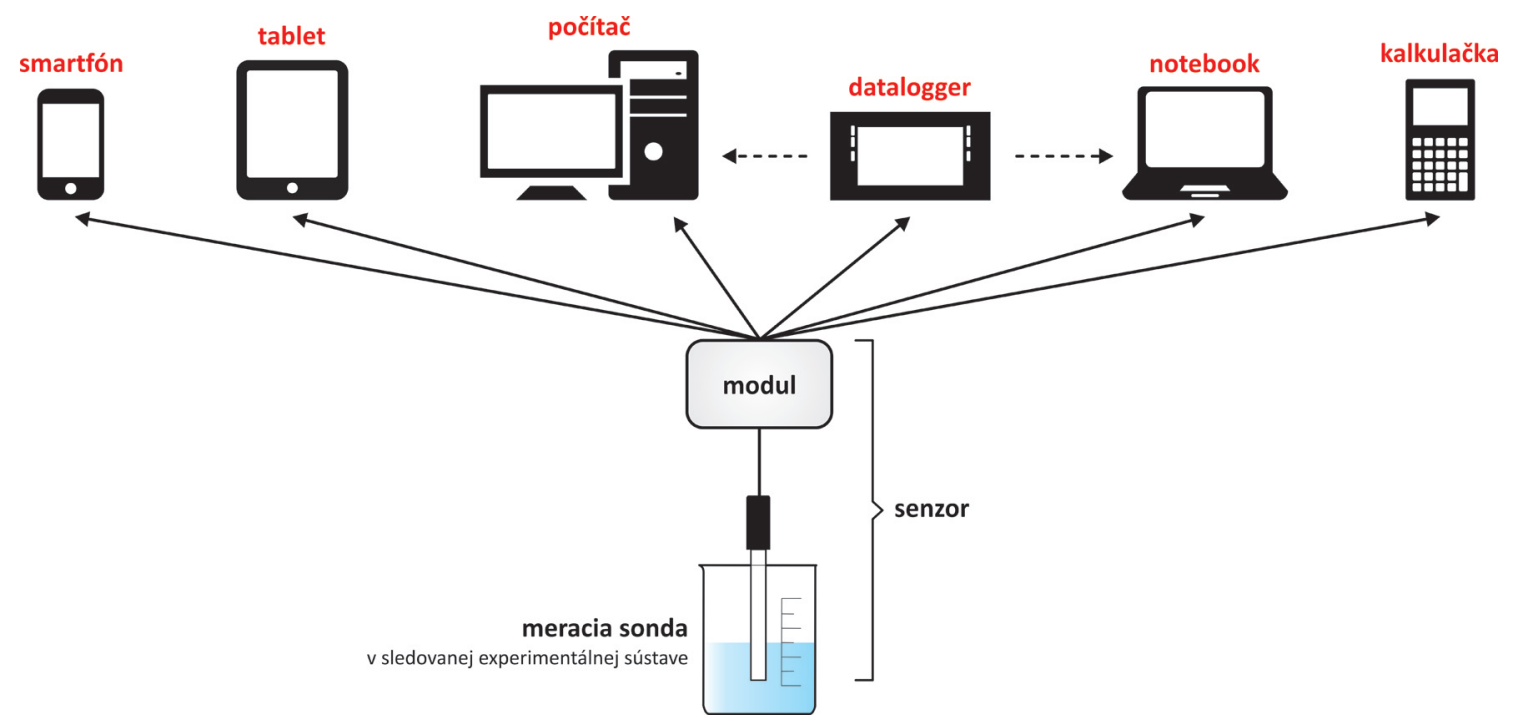

Obr. 1: Príklad experimentálneho usporiadania meracieho systému s rôznymi koncovými zariadeniami

niektoré štúdie, je tiež silným motivačným činitelom (Urban-Woldron et al., 2013; Skoršepa et al., 2014; Skoršepa \& Tortosa Moreno, 2014; Skoršepa, 2015; Skoršepa \& Šmejkal, 2018).

\section{Empirická čast’}

\subsection{Zámer a ciele výskumu}

Stúdia pojednáva o rozdieloch vo vnímaní počítačom podporovaného experimentovania žiakmi pri použití dvoch odlišných technologických riešení - koncových zariadení školských počítačových meracích systémov. Vytvorili sme sadu štyroch laboratórnych úloh, na ktorých pracovali dve skupiny žiakov. Kým jedna z nich využívala ako koncové zariadenia meracích systémov notebooky, druhá skupina (pri použití toho istého meracieho systému) na tento účel používala tablety. Cielom výskumu je zistit, či rozdielne technologické prístupy majú potenciál generovat štatisticky významné rozdiely vo vnímaní tohto typu experimentovania samotnými žiakmi. Stúdia bola inšpirovaná komparatívnym výskumom Priesta a kol. (2014), v ktorom bolo analogickým spôsobom porovnávané vnímanie experimentálnej práce žiakov s notebookmi a dataloggermi ako koncovými zariadeniami školských meracích systémov.

\subsection{Výskumná vzorka}

Výskumu sa celkovo zúčastnilo 115 žiakov (z toho 60 dievčat) z dvoch slovenských gymnázií vo veku 15-18 rokov (priemerný vek $M=16,325, S D=0,844$ ), pričom $17 \mathrm{z}$ nich uviedlo, že s podobnými experimentami majú predchádzajúcu skúsenost́. S notebookom ako koncovým zariadením pracovalo spolu 44 žiakov. 42 z nich uviedlo, že dané zariadenie používajú denne a majú s ním bohaté užívatelské skúsenosti. S tabletom ako koncovým zariadením pracovalo v štúdii 71 žiakov, z toho 51 uviedlo, že s ním majú každodenné užívatel'ské skúsenosti. Väčšina žiakov pracovala len na jednej z vytvorených laboratórnych aktivít, s výnimkou jedenástich z nich, ktorí v priebehu štúdie realizovali dve experimentálne aktivity. Dohromady sme teda so 115 žiakmi získali 126 výstupov (Horváthová, 2018). V tab. 1 je uvedený počet realizovaných aktivít s použitím oboch koncových zariadení. Dodávame, že hoci predchádzajúcu experimentálnu skúsenost' s prácou s počítačovými meracími systémami uviedlo 17 (14,78 \%) zo 115 respondentov, pri vyhodnocovaní výsledkov (napríklad vo vztiahu k rozdielnym východiskovým predpokladom žiakov) to neberieme do úvahy, pretože ich skúsenost’ bola len jednorazová, neperiodická, realizovaná len v rámci prezentačných dní na niektorej z vysokých škôl, a nemala teda cielený edukačný, ale skôr prezentačný, atrakčný a motivačný charakter.

Tab. 1: Počet realizovaných experimentov vo vzṫahu k druhu koncového zariadenia meracieho systému a ku konkrétnej realizovanej aktivite

\begin{tabular}{|c|c|c|c|c|c|}
\hline & Aktivita 1 & Aktivita 2 & Aktivita 3 & Aktivita 4 & $N$ \\
\hline Tablet & 13 & 36 & 10 & 12 & $\overline{71}$ \\
\hline Notebook & 11 & 11 & 17 & 16 & 44 \\
\hline & & & Celkový & et prípadov: & $\overline{126}$ \\
\hline
\end{tabular}




\subsection{Technické zázemie}

Všetky laboratórne úlohy boli realizované počítačovými meracími systémami firmy Vernier (Vernier Software \& Technology, 2019), a to vrátane potrebnej softvérovej výbavy. Obe skupiny žiakov teda pracovali s rovnakými senzormi a modulmi, avšak tie boli pripojené k rozdielnym koncovým zariadeniam: tabletom alebo notebookom. V súlade s tým sa, samozrejme, líšila aj softvérová podpora oboch porovnávaných prístupov. Kým skupina žiakov pracujúca s notebookmi využívala softvérovú aplikáciu Logger Pro 3 pre systém Windows, skupina pracujúca s tabletmi využívala vol’ne dostupnú aplikáciu Graphical Analysis pre systém Android. Káblové pripojenie senzorov k notebookom bolo realizované prostredníctvom jednotiek LabQuest 2, resp. LabQuest Mini. Na druhej strane, spojenie senzorov s tabletmi bolo bezdrôtové, zabezpečené prostredníctvom dostupných Bluetooth adaptérov firmy Vernier (Vernier Software \& Technology, 2019).

\subsection{Laboratórne aktivity}

V štúdii boli použité štyri experimentálne aktivity, pochádzajúce z dostupných zdrojov (uvedených nižšie) a upravené pre účely nášho výskumu. Dve z nich boli založené na meraní hodnôt $\mathrm{pH}$, d’alšie dve boli orientované na meranie teploty. Štruktúra aktivít vychádza z nedávno navrhnutej didaktickej sekvencie (Tortosa Moreno, 2012), ktorá čerpá z prvkov výskumne ladenej koncepcie vo vyučovaní (IBSE) (Banchi \& Bell, 2008; Aksela, 2011; Held et al., 2011; Čtrnáctová et al., 2012), pričom v najdôležitejších častiach aktivity je žiak vedený trojkrokovým didaktickým algoritmom POE (Predict - Observe - Explain) (White \& Gunstone, 1992), ktorý výrazne pripomína postupnost' krokov používanú vo vedeckom experimentovaní. Krátky opis jednotlivých aktivít prinášame v nasledujúcom texte.

Aktivita 1: Ako uhasit pálenie záhy je zameraná na chemické riešenie problému z bežného života spojeného s refluxom, ktorý sa prejavuje takzvaným pálením záhy. Úlohou žiakov je vytvorit laboratórny model žalúdka a následne, pomocou modulu na meranie $\mathrm{pH}$, experimentálne otestovat̉ účinnost’ dostupných antacíd (Skoršepa \& Melicherčík, 2001; Skoršepa, 2012, 2014).

Aktivita 2: Ako „rozpustit“ globálny problém sa zaoberá riešením globálneho problému spôsobeného nadmernou produkciou oxidu uhličitého a jeho hromadením v atmosfére. Žiaci experimentálne overujú účinnost̉ odvážnej alternatívnej myšlienky zavádzat̉ oxid uhličitý do oceánov, pričom pracujú s modulom na meranie pH (Tolvanen, 2012).

Aktivita 3: Tepelné zmeny endotermických a exotermických reakcií je založená na sledovaní tepelného efektu (pomocou modulu na meranie teploty) jednoduchej reakcie kyseliny octovej (octu) a hydrogenuhličitanu sodného (sódy bikarbóny), pričom úlohou žiakov je na základe získaného grafu určit, či ide o endotermickú alebo exotermickú reakciu.

Aktivita 4: Tepelné zmeny redoxných reakcií je zameraná na sledovanie tepelných zmien (pomocou modulu na meranie teploty) prebiehajúcich pri redoxnej reakcii horčíka s kyselinou chlorovodíkovou. Žiaci na základe získaného grafu určia, či ide o endotermickú alebo exotermickú reakciu.

Ku každej aktivite bol vytvorený pracovný list so špecifickou štruktúrou obsahujúcou tri hlavné časti. Prvá čast je motivačným úvodom (príp. príbehom), z ktorého vyplýval problém (výskumná otázka), ktorý bol základom riešenia experimentálnej aktivity. Jej súčastou boli úlohy zamerané na zopakovanie a aktiváciu nevyhnutne potrebných žiakových vedomostí súvisiacich s riešenou problematikou. Druhá časţ pracovného listu obsahovala konkrétne informácie potrebné na realizáciu samotného experimentu, napr. zoznam potrebných pomôcok, chemikálií, postup práce (schému) a pod. Posledná čast pracovného listu obsahovala úlohy, ktoré boli žiakovi nápomocné pri vyhodnocovaní a interpretácii získaných experimentálnych dát.

\subsection{Výskumné nástroje}

Primárnym zdrojom spätnej väzby bol v našej štúdii dotazník, ktorý bol respondentom administrovaný bezprostredne po realizácii experimentálnych aktivít. Jeho štruktúra a obsah vychádzajú z analogického nástroja vytvoreného v projekte ASELL - Advancing Science by Enhancing Learning in the Laboratory (ASELL, 2014). Hoci tento nástroj bol pôvodne mienený len na účely podobných skúmaní vo vyučovaní fyzikálnej chémie, neskôr bol rozšírený na oblastł chémie vo všeobecnosti (Buntine et al., 2007; George et al., 2009), a po d’alších úpravách je dokonca použitelný v akejkolvek vedeckej oblasti (Yeung et al., 2011). Pôvodný nástroj obsahuje 14 položiek Likertovho typu a 5 otvorených položiek. Pre náš výskum sme vytvorili podobný dotazník obsahujúci 8 položiek Likertovho typu, 2 dichotomické položky typu áno/nie a 2 otvorené položky (Horváthová, 2018). Položky Likertovho typu mali charakter pozitívnych deklaratívnych výrokov, v ktorých respondenti vyjadrovali mieru svojho súhlasu (resp. nesúhlasu) na 
pätstupňovej škále od -2 (úplne nesúhlasím), cez nulu (neutrálny bod, bez názoru, resp. neviem sa rozhodnút), po +2 (úplne súhlasím).

Doplňujúce dáta nám tiež poskytli samotné pracovné listy žiakov, v ktorých sme sa zamerali na kvalitatívne vyhodnotenie špecificky zvolených úloh orientovaných najmä na porozumenie chemickej podstaty sledovaného procesu prostredníctvom grafu.

Pomocným nástrojom na získanie spätnoväzbových údajov v našej štúdii bol rozhovor, ktorý bol so žiakmi realizovaný počas celej doby experimentovania. Rozhovor bol priebežne vedený so všetkými pracovnými tímami žiakov a bol cielene zameraný na získanie informácií o ich vnímaní experimentovania prostredníctvom rôznych technologických prístupov, ich názorov, pocitov a prípadných odporúčaní viažucich sa k uskutočňovanej aktivite alebo k samotnému meraciemu zariadeniu. Po ukončení aktivít bola so žiakmi v rovnakom duchu vedená diskusia, tentokrát však s celou experimentálnou triedou.

\subsection{Spracovanie výskumných dát}

Na kvantitatívne spracovanie získaných dát sme použili metódy deskriptívnej štatistiky a komparatívnej štatistickej analýzy. Zistenie štatistickej signifikantnosti generovaných rozdielov sme v prípade komparatívnej analýzy, vzhl’adom na charakter našich dát, realizovali prostredníctvom neparametrickej štatistickej metódy - Mannovho-Whitneyovho U testu (Mann \& Whitney, 1947). Velkost́ účinku (Effect Size) v prípadoch komparácií so štatisticky významným rozdielom sme na základe relevantných odporúčaní (Field, 2013) merali prostredníctvom korelačného koeficientu $(r)$ konvertovaného zo z-skóre Mannovho-Whitneyovho U testu podla vzţahu definovaného Rosenthalom (1991, s. 19). Interpretácia hodnôt velkosti účinku bola realizovaná na základe odporúčaní Cohena (1988, 1992). Získané dáta boli spracované štatistickým softvérovým balíkom IBM SPSS ver. 18 (SPSS Inc., 2009).

\section{Výsledky}

V štúdii sme sa zamerali na sledovanie a vyhodnotenie rôznych vztahov a $\mathrm{k}$ nim patriacich podmieňujúcich faktorov. Najdôležitejšou častou výskumu bolo porovnávanie žiackeho vnímania počítačom podporovaného experimentovania pri použití dvoch odlišných koncových hardvérových, a zároveň aj softvérových technológií: notebookov a tabletov.

Na obr. 2 sú zobrazené stredné hodnoty odpovedí žiakov na dotazníkové položky Likertovho typu nezávisle na aktivite, ktorú vykonávali. Napriek tomu, že sme zaznamenali aj niekolko individuálnych negatívnych odpovedí, je zrejmé, že všetky priemerné odpovede boli pozitívne a líšia sa len mierou pozitívneho vyjadrenia.

Položka 01: Kvalita poskytnutých informácií
Položka 02: Jednoduchost' práce s koncovým zariadením
Položka 03: Jednoduchost' manipulácie s grafom
Položka 04: Jednoduchost' odčítania dát z grafu
Položka 05: Benefit tímovej práce
Položka 06: Dostatok času na vyplnenie pracovného listu
Položka 07: Vhodnost' experimentu pre učenie sa chémie
Položka 08: Porozumenie reakcii pomocou grafu

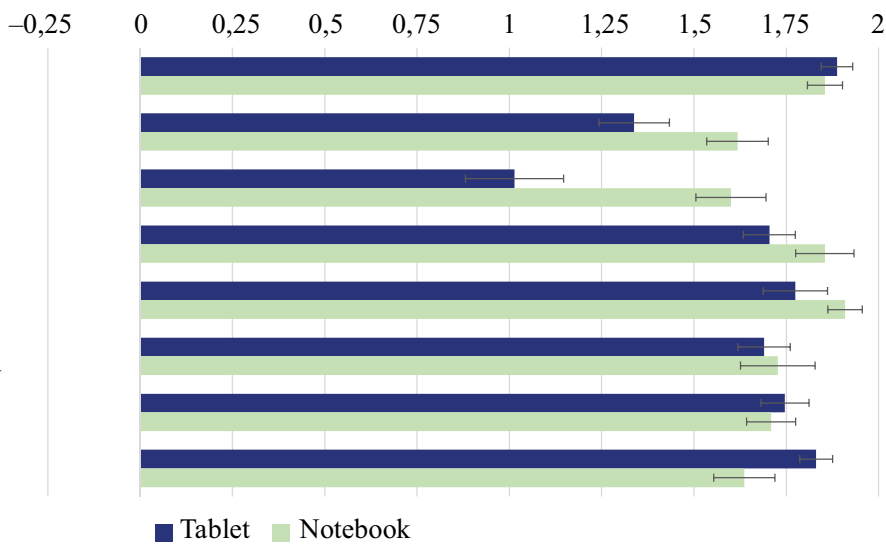

*Chybové úsečky predstavujú štandardné chyby merania (Standard Error).

Obr. 2: Stredné hodnoty odpovedí žiakov na dotazníkové položky Likertovho typu pre všetky aktivity (celkový pohlad, nezávislý na realizovanej aktivite)

Najviac kladných odpovedí sme v priemere zaznamenali pri položkách týkajúcich sa poskytnutých informácii pred experimentovaním a počas experimentovania (P01) a benefitu tímovej práce (P05). Najmenej pozitívnych odpovedí bolo zaznamenaných pri položkách týkajúcich sa jednoduchosti práce s koncovým zariadením (P02) a manipulácie s grafom (P03). Zdá sa, že žiaci boli spokojní s informáciami a odbornou pomocou učitela počas experimentovania, skupinovú prácu považovali za pozitívum, avšak vnímanie použivaného koncového zariadenia sa ukazuje ako nejednotné, závisiace na type daného prístroja. S tým súvisia aj niektoré komplikácie, s ktorými sa žiaci stretli pri manipulácii s grafmi. 
Interesantnejšie zistenia sme zaznamenali prostredníctvom komparatívnej analýzy oboch skupín pracujúcich s rozdielnymi technológiami. Pri porovnaní odpovedí žiakov pracujúcich s notebookmi a žiakov pracujúcich s tabletmi odhalil Mannov-Whitneyov U test signifikantné rozdiely v troch položkách týkajúcich sa jednoduchosti práce s koncovým zariadením (P02), jednoduchosti manipulácie s grafom (P03) a jednoduchosti odčitavania dát z grafu (P04). Štatistické dáta ku komparácii týchto položiek uvádzame v tab. 2.

Tab. 2: Diferencie medzi žiakmi pracujúcimi s notebookmi a žiakmi pracujúcimi s tabletmi (celkový pohlad, nezávislý na realizovanej aktivite)

$N=126 ;$ uvedené sú len položky so štatisticky významným rozdielom

$M R_{\mathrm{TBL}}$ - priemerné poradie (Mean Rank) pre žiakov pracujúcich s tabletmi

$M R_{\mathrm{NTB}}$ - priemerné poradie (Mean Rank) pre žiakov pracujúcich s notebookmi

\begin{tabular}{|c|c|}
\hline Položka & Mannov-Whitneyov U test* \\
\hline & $\bar{U}=2320,5 ; z=2,065 ; p=0,039$ \\
\hline 02 Jednoduchost práce s koncovým zariadením. & $\begin{array}{l}M R_{\mathrm{TBL}}=58,32 ; M R_{\mathrm{NTB}}=70,19 \\
r=0,18\end{array}$ \\
\hline 03 Jednoduchost manipulácie s grafom & $\begin{array}{l}U=2520,5 ; z=3,103 ; p=0,002 \\
M R_{\mathrm{TBL}}=55,50 ; M R_{\mathrm{NTB}}=73,83 \\
r=0,28\end{array}$ \\
\hline 04 Jednoduchost’ odčítavania dát z grafu & $\begin{array}{l}U=2240,0 ; z=2,145 ; p=0,032 \\
M R_{\mathrm{TBL}}=59,45 ; M R_{\mathrm{NTB}}=68,73 \\
r=0,19\end{array}$ \\
\hline
\end{tabular}

* Zobrazené sú asymptotické signifikancie.

Je zaujímavé, že štatisticky významné diferencie sme zaznamenali práve v oblastiach, ktoré sa najviac týkajú samotných koncových zariadení meracích systémov. Žiaci oboch porovnávaných skupín teda prácu s nimi nevnímali rovnako, aj ked’ obe použité zariadenia boli nimi prijímané pozitívne. Na základe hodnôt priemerných poradí (Mean Rank, MR) v tab. 2 sa domnievame, že práca s notebookmi bola žiakmi vnímaná pozitívnejšie ako práca s tabletmi. Pre úplnost̉ však musíme dodat, že zistené hodnoty korelačného koeficientu $(r)$ sa vo všetkých troch prípadoch nachádzajú pod hraničnou hodnotou 0,30, čo podla Cohena $(1988,1992)$ predstavuje nízku hodnotu velkosti sledovaného účinku (Effect Size).

Pozitívnejšie vnímanie manipulácie s grafmi a ich efektívnejšie vyhodnocovanie skupinou žiakov pracujúcou s notebookmi potvrdila aj kvalitatívna analýza pracovných listov oboch skupín žiakov. Z nej vyplynulo, že žiaci pracujúci s notebookmi boli vo všeobecnosti schopní presnejšie odčítat kritické body na jednotlivých krivkách a správnejšie interpretovat̉ chemické zdôvodnenia javov, ktoré boli týmito krivkami reprezentované.

Samozrejme, tieto rozdiely nájdeme nielen pri súhrnnom pohlade na všetky realizované aktivity, ale aj vtedy, ak aktivity budeme brat do úvahy jednotlivo, samostatne. Najmarkantnejšie diferencie sme pritom zaznamenali pri aktivite Ako uhasit’ pálenie záhy (obr. 3), kde boli v signifikantne rozdielne vnímaných položkách týkajúcich sa jednoduchosti práce s koncovým zariadením (P02) a jednoduchosti manipulácie s grafom (P03) zistené velkosti účinku dokonca na strednej $(r=0,45)$ a vysokej $(r=0,60)$ úrovni (tab. 3).

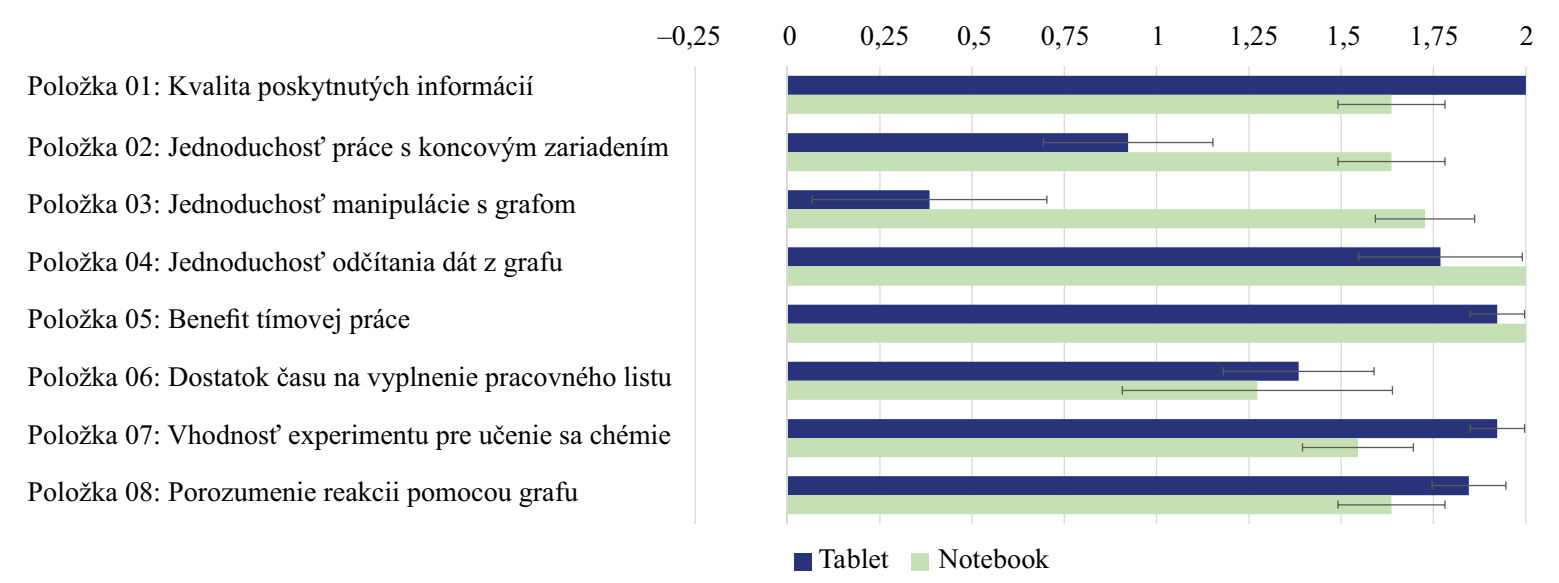

*Chybové úsečky predstavujú štandardné chyby merania (Standard Error).

Obr. 3: Stredné hodnoty odpovedí žiakov na dotazníkové položky Likertovho typu pre aktivitu Ako uhasit’ pálenie záhy 
Tab. 3: Diferencie medzi žiakmi pracujúcimi s tabletmi a žiakmi pracujúcimi s notebookmi pre aktivitu $A k o$ uhasit pálenie záhy

$N=24 ;$ uvedené sú len položky so štatisticky významným rozdielom

$M R_{\mathrm{TBL}}$ - priemerné poradie (Mean Rank) pre žiakov pracujúcich s tabletmi

$M R_{\mathrm{NTB}}$ - priemerné poradie (Mean Rank) pre žiakov pracujúcich s notebookmi

\begin{tabular}{ll}
\hline Položka & Mannov-Whitneyov U test* \\
\hline \multirow{2}{*}{ 02 Jednoduchost práce s koncovým zariadením } & $U=106,5 ; z=2,223 ; p=0,041$ \\
& $M R_{\mathrm{TBL}}=9,81 ; M R_{\mathrm{NTB}}=15,68$ \\
& $r=0,45$ \\
\hline \multirow{2}{*}{ 03 Jednoduchost manipulácie s grafom } & $U=119,0 ; z=2,933 ; p=0,005$ \\
& $M R_{\mathrm{TBL}}=8,85 ; M R_{\mathrm{NTB}}=16,82$ \\
& $r=0,60$ \\
\hline
\end{tabular}

*Zobrazené sú asymptotické signifikancie.

Pri podrobnejšom skúmaní sme si všimli, že signifikantné diferencie sú generované najmä aktivitami, pri ktorých sa meria pH (tab. 4). Pritom vo všetkých štatisticky signifikantne rozdielne vnímaných aspektoch žiaci pozitívnejšie vnímajú prácu s notebookmi. V aktivitách orientovaných na sledovanie tepelného efektu chemických reakcií rozdiely medzi porovnávanými skupinami pracujúcimi s notebookmi a tabletmi síce existujú, nie sú však štatisticky významné.

Tab. 4: Diferencie medzi žiakmi pracujúcimi s tabletmi a žiakmi pracujúcimi s notebookmi pre aktivity s meraním pH

$N=71 ;$ uvedené sú len položky so štatisticky významným rozdielom $M R_{\text {TBL }}$ - priemerné poradie (Mean Rank) pre žiakov pracujúcich s tabletmi $M R_{\mathrm{NTB}}$ - priemerné poradie (Mean Rank) pre žiakov pracujúcich s notebookmi

\begin{tabular}{ll}
\hline Položka & Mannov-Whitneyov U test* \\
\hline \multirow{3}{*}{ 03 Jednoduchost manipulácie s grafom } & $U=793,0 ; z=3,361 ; p=0,001$ \\
& $M R_{\mathrm{TBL}}=30,82 ; M R_{\mathrm{NTB}}=47,55$ \\
& $r=0,40$ \\
\hline \multirow{2}{*}{ 04 Jednoduchost odčítania dát z grafu } & $U=660,0 ; z=2,394 ; p=0,005$ \\
& $M R_{\mathrm{TBL}}=33,53 ; M R_{\mathrm{NTB}}=41,50$ \\
& $r=0,28$ \\
\hline
\end{tabular}

*Zobrazené sú asymptotické signifikancie.

Zaujímalo nás tiež, ako prácu s rozdielnymi zariadeniami vnímajú rozdielne pohlavia. Chlapci aj dievčatá vo všetkých položkách dotazníka týkajúcich sa koncového zariadenia (P02, P03 a P04) preferovali notebook pred tabletom, avšak len pri dievčatách sme v tomto smere zaznamenali štatisticky významné indície (tab. 5) na úrovni strednej alebo nízkej vel'kosti účinku.

Tab. 5: Diferencie medzi dievčatami pracujúcimi s tabletmi a dievčatami pracujúcimi s notebookmi (celkový pohlad, nezávislý na realizovanej aktivite)

$N=66 ;$ uvedené sú len položky so štatisticky významným rozdielom

$M R_{\mathrm{TBL}}$ - priemerné poradie (Mean Rank) pre dievčatá pracujúce s tabletmi

$M R_{\mathrm{NTB}}$ - priemerné poradie (Mean Rank) pre dievčatá pracujúce s notebookmi

\begin{tabular}{ll}
\hline Položka & Mannov-Whitneyov U test* \\
\hline \multirow{2}{*}{ 03 Jednoduchost manipulácie s grafom } & $U=733,5 ; z=3,054 ; p=0,002$ \\
& $M R_{\mathrm{TBL}}=28,19 ; M R_{\mathrm{NTB}}=41,17$ \\
& $r=0,38$ \\
\hline \multirow{2}{*}{ 04 Jednoduchost odčítania dát z grafu } & $\begin{array}{l}U=631,0 ; z=1,972 ; p=0,049 \\
\end{array}$ \\
& $\begin{array}{l}\mathrm{TBBL} \\
r=0,24\end{array}$ \\
\hline
\end{tabular}

*Zobrazené sú asymptotické signifikancie.

Skúmali sme tiež, či na prácu s rozdielnymi zariadeniami má vplyv vek (resp. ročník štúdia) respondentov, avšak drobné náznaky črtajúcich sa vztahov a závislostí sa nakoniec ukázali ako štatisticky nevýznamné. 
Otvorené otázky výskumného nástroja (dotazníka) boli určené najmä na zistenie tažšie meratelnej spätnej väzby, názorov, pocitov a odporúčaní žiakov smerom k realizovaným aktivitám aj použitej technike. Ich vyhodnotením sme zistili, že už nemajú zásadný význam v posune alebo prehodnotení záverov prezentovaných vyššie. Získané odpovede žiakov sme roztriedili do niekolkých najčastejšie sa opakujúcich kategórií. Frekvencie odpovedí žiakov pracujúcich s rozdielnymi zariadeniami sme tiež podrobili komparatívnej analýze, avšak štatisticky významné zistenia neboli zaznamenané. Najfrekventovanejšie odpovede žiakov na otázku: „Čo sa vám počas experimentovania najviac páčilo?" uvádzame vo forme početností a percentuálnych vyjadrení v tab. 6 .

Tab. 6: Najfrekventovanejšie odpovede žiakov na otvorenú otázku dotazníka týkajúcu sa najprítažlivejšej časti experimentovania

\begin{tabular}{lcrrr}
\hline \multirow{2}{*}{ Odpoved' } & \multicolumn{2}{c}{ Tablet } & \multicolumn{2}{c}{ Notebook } \\
\cline { 2 - 5 } & Početnost' & \multicolumn{1}{c}{ Početnost' } & \multicolumn{1}{c}{$\%$} \\
\hline Pozorovanie chemickej reakcie & 18 & 14,29 & 23 & 18,25 \\
Vydychovanie $\mathrm{CO}_{2}$ do vody & 17 & 13,49 & 8 & 6,35 \\
Práca s technikou & 12 & 9,52 & 10 & 7,94 \\
Sledovanie grafu & 10 & 7,94 & 8 & 6,35 \\
Praktická čast & 7 & 5,56 & 0 & 0,00 \\
Odčítavanie údajov z grafu & 5 & 3,97 & 2 & 1,59 \\
Práca s grafom & 5 & 3,97 & 0 & 0,00 \\
Samotné meranie & 3 & 2,38 & 3 & 2,38 \\
Všetko & 2 & 1,59 & 1 & 0,79 \\
\hline
\end{tabular}

Samotná chemická reakcia bola podl’a žiakov jednou z najzaujímavejších častí experimentovania, túto odpoved' uviedlo 14,29 \% žiakov pracujúcich s tabletom a 18,25\% žiakov pracujúcich s notebookmi. Žiaci oceňovali najmä také činnosti, pri ktorých mali pocit priameho zainteresovania do skúmaného procesu. Pri rozhovoroch so žiakmi sme zistili, že v niektorých prípadoch ich praktická časṫ aktivity (napr. vydychovanie oxidu uhličitého do vody) zaujala najmä z dôvodu, že sa „cítili byt’ súčastou samotného experimentu“. Práca s technikou bola taktiež frekventovanou odpoved’ou, čo však bolo možné predpokladat', kedže podobné experimenty boli pre prevažnú väčšinu žiakov novinkou.

Na druhej strane sme žiakom položili otázku, ktorá čast’ experimentu by podla nich potrebovala vylepšit. Najfrekventovanejšie odpovede uvádzame vo forme početností a percentuálnych vyjadrení v tab. 7.

Tab. 7: Najfrekventovanejšie odpovede žiakov na otvorenú otázku dotazníka, týkajúcu sa odporúčaní na vylepšenie realizovanej experimentálnej činnosti

\begin{tabular}{lcrrr}
\hline \multirow{2}{*}{ Odpoved' } & \multicolumn{2}{c}{ Tablet } & \multicolumn{2}{c}{ Notebook } \\
\cline { 2 - 5 } & Početnost' & \multicolumn{1}{c}{$\%$} & Početnost' & $\%$ \\
\hline Nič & 30 & 23,81 & 32 & 25,40 \\
Fungovanie techniky & 8 & 6,35 & 2 & 1,59 \\
Manipulácia s technikou & 2 & 1,59 & 2 & 1,59 \\
Aktualizácia a inovovanie softvéru & 1 & 0,79 & 1 & 0,79 \\
Zabezpečit WiFi & 1 & 0,79 & 0 & 0,00 \\
Viac praxe s tabletom na hodinách chémie & 1 & 0,79 & 0 & 0,00 \\
Odčítanie grafu na tablete & 1 & 0,79 & 0 & 0,00 \\
Lepšie zaškolenie práce so softvérom & 0 & 0,00 & 2 & 1,59 \\
\hline
\end{tabular}

Žiaci boli s priebehom experimentovania v priemere spokojní a väčšina by na realizovanom experimente nevylepšila nič. Túto odpoved' sme zaznamenali až v 23,81 \% odpovedí od žiakov pracujúcich s tabletmi a 25,4 \% od žiakov pracujúcich s notebookmi. Žiaci by odporúčali vylepšit manipuláciu s niektorými technickými zariadeniami alebo aktualizovat̉ softvérovú aplikáciu. Z diskusie so žiakmi vyplynula aj potreba lepšieho zaškolenia, resp. častejšej praxe s meracími a počítačovými zariadeniami.

\section{Limity výskumu}

Musíme zdôraznit, že dáta boli v našom výskume získané len z dvoch slovenských gymnázií, čo neumožňuje generalizovat naše zistenia pre všetky školy v Slovenskej republike, alebo dokonca vyslovit ešte všeobecnejšie závery. Považujeme to za najvážnejší limit nášho výskumu. Takéto obmedzenie, samozrejme, nie je účelné, avšak museli sme (okrem iného) vychádzat najmä z materiálno-technických možností a predpokladov škôl, kde sme výskum realizovali, a zvažovat’ aj časovú náročnost' realizovaných aktivít, a to najmä 
s ohladom na nevelkú skúsenost respondentov s počítačom podporovaným experimentovaním. V tejto súvislosti možno tiež za isté obmedzenie považovaṫ fakt, že žiaci zahrnutí do štúdie nemali rovnaké skúsenosti s prácou v počítačom podporovanom chemickom laboratóriu. Na druhej strane to podporuje variabilitu nášho výskumného súboru.

\section{Diskusia}

Diskusiu k zisteným výsledkom čiastočne uvádzame aj bezprostredne pri ich prezentácii. Najväčšiu podobnost̉ s našim výskumom má (z nám dostupných informácií) štúdia Priesta a kol. (2014), aj ked’ bola realizovaná za rozdielnych podmienok a jej cielom bolo porovnávanie vnímania iných technologických prístupov používaných v počítačom podporovanom experimentovaní. Oba výskumy však majú isté vzájomne korešpondujúce črty, ktoré v diskusii na niekolkých miestach porovnávame.

Už tradične pri podobných skúsenostiach väčšina žiakov vyjadruje velkú spokojnost̉ s experimentovaním prostredníctvom počítačových meracích systémov (Aksela, 2005; Pierri et al., 2008; Skoršepa, 2015). Aj teraz sme dokázali, že najprirodzenejšou činnostou, ktorou je potrebné u žiakov podporovat záujem o chémiu, je jej organická súčast - laboratórna práca.

Jedným z prvých markantných zistení nášho výskumu je fakt, že všetky priemerné odpovede žiakov na dotazníkové položky Likertovho typu mali pozitívny charakter. Zistenie prevažujúceho pozitívneho vztahu k realizovaným aktivitám vo väčšine sledovaných aspektov však nie je úplne prekvapujúce. Takmer rovnaký trend sledujeme aj vo výsledkoch štúdie Priesta a kol. (2014). Všeobecne pozitívny vzţah respondentov k počítačom podporovanému experimentovaniu však dokladujú aj staršie štúdie (Atar, 2002; Metcalf \& Tinker, 2004). Ako sme, okrem iného, uviedli v predchádzajúcej časti, najviac priemerných kladných odpovedí bolo zaznamenaných pri položkách týkajúcich sa poskytnutých informácii pred experimentovaním a počas experimentovania (P01) a benefitu tímovej práce (P05). Práve oblast́ tímovej práce vnímali podobne pozitívne aj respondenti výskumu Priesta a kol. (2014). Niektorí žiaci by sami uvítali možnost’ lepšie sa zaškoliț v práci s technickými zariadeniami a softvérovými aplikáciami, prípadne by podobné experimenty radi realizovali v chemickom laboratóriu častejšie. Najviac sa žiakom páčila predovšetkým samotná skúmaná chemická reakcia a práca s príslušnou technikou. Konkrétne sledované chemické procesy boli pozitívne vnímané už aj v iných štúdiách zameraných na skúmanie rozličných dimenzií motivácie žiakov vo vzţahu k počítačom podporovanému experimentovaniu (Tortosa Moreno et al., 2013; Skoršepa, 2015). Zaujímavé zistenia boli tiež zaznamenané v zmysle pocitu zainteresovanosti žiakov, ktorí sa pri realizácii niektorých aktivít „cítili byt súčastou samotného experimentu“. Analogické vyjadrenia nachádzame aj v starších výskumoch Beichnera (1990) a Aksely (2005). Psychológovia Ryan a Deci (2000) v tejto súvislosti dokonca predpokladajú, že takéto intenzívne zapojenie žiaka do experimentu posilňuje jeho pocit kompetentnosti, čo ulahčuje proces zvnútornenia cielov vzdelávania. Prítažlivost̉ samotnej počítačovej meracej techniky dokonca spôsobuje, pravdepodobne vzhladom na to, že generácia dnešných žiakov má k technickým zariadeniam velmi blízko, že jej využitie počas chemického experimentovania oslovilo aj takých žiakov, ktorí o chémiu v minulosti nejavili velký záujem.

Cielom našej štúdie však bolo preskúmat žiakove vnímanie laboratórnej činnosti podporovanej počítačovými zariadeniami so špecifickým zameraním na porovnanie vnímania rozdielnych technologických riešení koncových zariadení meracích systémov - tabletov, resp. notebookov.

$\mathrm{V}$ poslednom čase sa aj v pedagogickom prostredí do popredia pozornosti dostávajú práve dotykové technológie (tablety, smartfóny). Dotykový spôsob ovládania, kvôli svojej jednoduchosti a prístupnosti, tieto zariadenia istým spôsobom technologicky preferuje pred staršími technológiami používanými na školách v minulosti (Reychav \& Wu, 2015; Shuler et al., 2013). Niektorí autori tiež zdôrazňujú, že tablety je výhodnejšie na vyučovaní používat okrem iného preto, že ich žiaci aj v súkromí používajú na pravidelnej báze (Ward et al., 2013; Hadlington et al., 2019). V našej štúdii sme preto boli zvedaví, či dotykové technológie (reprezentované tabletmi) majú potenciál konkurovat’ staršej technológii aj vtedy, ak sú súčastou počítačového meracieho systému. Ukazuje sa však, že napriek mnohým pozitívnym ohlasom, z ktorých však žiadny nezohladňoval ich efektivitu ako súčasti počítačového meracieho systému, práve pri takejto aplikácii nemusia predstavovat najúčinnejšiu alternatívu. Naša štúdia totiž naznačuje, že použitie notebookov, hoci sú staršou technológiou, je v porovnaní s dotykovými zariadeniami ako sú tablety, žiakmi vnímané pozitívnejšie. Možno zosumarizovat, že výsledky nášho skúmania poskytujú istý empirický dôkaz o tom, že žiaci preferujú a sú efektívnejší pri práci s notebookmi (v porovnaní s tabletmi). Hoci oba technologické prístupy boli účinné a celkovo žiakmi vnímané pozitívne, rozdiely medzi nimi sa ukázali najmä pri činnostiach, ktoré boli pre žiakov problematickejšie. Žiaci pracujúci s tabletmi tažkopádnejšie operovali s grafmi a dokonca z nich menej presne odčítavali dôležité dáta (napr. minimum a maximum). Tieto skutočnosti sa potvrdili aj vyhodnotením pracovných listov žiakov. Pri rozhovoroch počas experimentovania žiaci vo všeobecnosti deklarovali efektívnejšiu manipuláciu s notebookmi, a to nielen pri ovládaní 
samotného merania, ale aj pri jeho spracovaní, vyhodnotení a interpretácii prostredníctvom vykreslených grafov. Navyše, naše výsledky ukazujú, že dievčatá sú vo vnímaní oboch použitých zariadení „citlivejšie" ako chlapci, ked' z pohladu štatistiky markantnejšie vyjadrujú pozitívnejší postoj k notebookom ako $\mathrm{k}$ tabletom.

Príčiny týchto zistení môžu byt rozličné, avšak na základe nevelkého objemu našich dát je tažké zhodnotit ich komplexnejšie. Ak sa však pokúsime dat do súvisu naše zistenia s najpríbuznejšou publikovanou štúdiou (Priest et al., 2014), domnievame sa, že v našom prípade môžeme vylúčit rovnaké zdôvodnenie, ako vo svojej štúdii prezentuje spomínaný autorský kolektív, kde sú zistenia v prospech notebookov (oproti dataloggerom) logicky zdôvodňované rozdielom medzi známou (notebook) a neznámou (datalogger) technológiou. V našom výskume sú notebooky, rovnako ako tablety, žiakom velmi blízke (teda rovnako známe) a pre väčšinu z nich práca s nimi predstavuje každodennú rutinu. Jedno z možných ponúkaných vysvetlení určite súvisí aj s rozdielnym spôsobom ovládania jednotlivých zariadení, ale aj s rozličnou „vyspelostou“ softvéru, ktorým jednotlivé zariadenia v súčasnosti disponujú. Naše zistenia teda úplne neodrážajú trend vyplývajúci zo všeobecne stúpajúcej tendencie používania a popularity práve dotykových technológií žiakmi, ktorý potvrdzujú aj nedávne výskumy (Chen, Chang \& Wang, 2008; Rideout, 2013, Simsek \& Dogru, 2014). Množstvo dalších štúdií skúma ich aplikáciu do rozličných pedagogických situácií, pričom sledujú široké spektrum didaktických a pedagogicko-psychologických aspektov ich použitia (Yang et al., 2015; Zydney \& Warner, 2016; Mang et al., 2017; Volk et al., 2017; Liu et al., 2017; Fu \& Hwang, 2018; Hadlington et al., 2019). Opät̆ však dodávame, že žiadny z týchto výskumov sa nezaoberal použitím tabletov (resp. dotykových technológií vo všeobecnosti) v experimentálnej časti vyučovania, teda ako súčastí meracích systémov. Niektoré z nich ukazujú, že pri implementácii tabletov do vyučovania je z hladiska jeho efektívneho použitia vo vyučovaní dôležitá nielen blízkost̉ tohto zariadenia žiakovi, ale aj špecifická rola učitela (Haksiz, 2014; Montrieux et al., 2014). Tento nesporne dôležitý fakt však v našom výskume nezohladňujeme. Naše výsledky čiastočne podporujú zaujímavé zistenie, že hoci používanie dotykových technológií má na školách medzi žiakmi stúpajúcu tendenciu, žiaci (najmä nižšieho veku) ich skôr vnímajú ako zariadenia na zábavu než na vzdelávanie (Oliemat et al., 2018).

\section{Záver}

Na záver nemožno neupozornit na istú analógiu s inými koncovými zariadeniami meracích systémov dataloggermi, ktoré boli v počítačom podporovanom experimentovaní kvôli predpokladaným pozitívnym črtám výrazne preferované približne od roku 2000 (Lavonen et al., 2003). Hoci o ich spornom prijatí žiakmi už dlhšiu dobu neoficiálne hovorili praktické skúsenosti ich používatelov (žiakov aj učitelov), až štúdia Priesta a kol. (2014) kvantitatívne potvrdila ich nižšiu účinnost v praxi v porovnaní s notebookmi.

Naša štúdia zatial nemá potenciál zovšeobecnit zistené závery o skúmanej problematike. Naznačuje však, že notebook je ako koncové zariadenie školského počítačového meracieho systému žiakmi vnímaný ako efektívnejšia alternatíva v porovnaní s tabletom. V každom prípade, vedomost o tom, že technológia má schopnoste signifikantne ovplyvňovat vnímanie žiakov vo vztahu $\mathrm{k}$ samotnému laboratórnemu meraniu, môže byt nápomocná pre autorov počítačom podporovaných aktivít, ktorí by pri ich navrhovaní mali brat do úvahy aj túto skutočnost. Uvedomujeme si však, že na zásadnejšie vyjadrenia by bolo potrebné zrealizovat dalšie skúmania, zvážit viac ovplyvňujúcich faktorov a tiež rozšírit vzorku zahrnutých respondentov. Preto našu štúdiu vnímame ako pilotnú prácu, ktorá naznačuje určité empirické vztahy, a zároveň dăš̌ie výskumné smerovania v tejto oblasti.

\section{Podakovanie}

Príspevok vznikol s podporou národného projektu ITMS 312011F057 - IT Akadémia, vzdelávanie pre 21. storočie.

\section{Literatúra}

Ambrose, B. S. (2004). Investigating student understanding in intermediate mechanics: Identifying the need for a tutorial approach to instruction. American Journal of Physics, 72(4), 453-459. https://doi.org/10.1119/1.1648684

Aksela, M. K. (2005). Supporting meaningful chemistry learning and higher-order thinking through computer-assisted inquiry: A design research approach [Dizertačná práca]. University of Helsinki.

Aksela, M. K. (2011). Engaging students for meaningful chemistry learning through microcomputer-based laboratory (MBL) inquiry. Educació Química EduQ, 9, 30-37. https://doi.org/10.2436/20.2003.02.66 
ASELL - Advancing science by enhancing learning in the laboratory website. (2014). http://www.physics.usyd.edu.au/asell/asell.site/

Atar, H. Y. (2002). Chemistry students' challenges in using MBL's in science laboratories. In P. A. Rubba, J. A. Rye, W. J. DiBiase, \& B. A. Crawford (Eds.), Proceedings of the 2002 Annual International Conference of the Association for the Education of Teachers in Science (pp. 2-23). Charlotte, Association for the Education of Teachers in Science.

Banchi, H., \& Bell, R. (2008). The many levels of inquiry. Science and Children, 46(2), 26-29.

Barton, R. (1997). How do computers affect graphical interpretation? School Science Review, 79(287), 55-60.

Beichner, R. J. (1990). The effect of simultaneous motion presentation and graph generation in a kinematics lab. Journal of Research in Science Teaching, 27(8), 803-815. https://doi.org/10.1002/tea.3660270809

Bernhard, J. (2003). Physics learning and microcomputer based laboratory (MBL) learning - effects of using MBL as a technological and as a cognitive tool. In D. Psillos, P. Kariotoglou, V. Tselfes, E. Hatzikraniotis, G. Fassoulopoulos, \& M. Kallery (Eds.), Science Education Research in the Knowledge-Based Society (pp. 323-331). Springer Netherlands. https://doi.org/10.1007/978-94-017-0165-5

Bílek, M., Kričfaluši, D., Budweiserová, K., \& Danielová, M. (2002). Digitální váhy a počítač ve výuce chemie. In M. Bílek (Ed.), Profil učitele chemie II.: Sborník př́spěvki̊ z jednání v sekcích XI. mezinárodní konference o výuce chemie (s. 206-209). Gaudeamus.

Borghi, L., De Ambrosis, A., Lunati, E., \& Mascheretti, P. (2001). In-service teacher education: An attempt to link reflection on physics subjects with teaching practice. Physics Education, 36(4), 299-305.

https://doi.org/10.1088/0031-9120/36/4/303

Brasell, H. (1987a). Effectiveness of a microcomputer-based laboratory in learning distance and velocity graphs [Dizertačná práca]. University of Florida.

Brasell, H. (1987b). The effect of real-time laboratory graphing on learning graphic representations of distance and velocity. Journal of Research in Science Teaching, 24(4), 385-395. https://doi.org/10.1002/tea.3660240409

Buntine, M. A., Read, J. R., Barrie, S. C., Bucat, R. B., Crisp, G. T., George, A. V., Jamie, I. M., \& Kable, S. H. (2007). Advancing chemistry by enhancing learning in the laboratory (ACELL): A model for providing professional and personal development and facilitating improved student laboratory learning outcomes. Chemistry Education Research and Practice, 8(2), 232-254. https://doi.org/10.1039/B6RP90033J

Chen, G., Chang, C., \& Wang, C. (2008). Ubiquitous learning website: Scaffold learners by mobile devices with information-aware techniques. Computers \& Education, 50(1), 77-90.

https://doi.org/10.1016/j.compedu.2006.03.004

Cohen, J. (1988). Statistical power analysis for the behavioral sciences. 2nd ed. Academic Press.

Cohen, J. (1992). A power primer. Psychological Bulletin, 112(1), 155-159.

https://doi.org/10.1037/0033-2909.112.1.155

Čtrnáctová, H., Č́žková, V., Hlavová, L., \& Řezníčková, D. (2012). Dovednosti žáků v badatelsky orientované výuce chemie. In J. Reguli (Ed.), Zborník z medzinárodnej konferencie „Aktuálne trendy vo vyučovaní prírodných vied (Smolenice 2012)“ (s. 31-36). Pedagogická fakulta Trnavskej univerzity.

Euler, M., \& Müller, A. (1999). Physics learning and the computer: A review, with a taste of meta-analysis. In M. Komorek, H. Behrendt, H. Dahncke, R. Duit, W. Gräber, \& A. Kross (Eds.), Second International Conference of the European Science Education Research Association (pp. 1-3). Kiel, European Science Education Research Association.

Field, A. (2013). Discovering statistics using IBM SPSS Statistics. 4th edition. SAGE Publications.

Fu, Q., \& Hwang, Q. (2018). Trends in mobile technology-supported collaborative learning: A systematic review of journal publications from 2007 to 2016. Computers \& Education, 119, 129-143.

https://doi.org/10.1016/j.compedu.2018.01.004

Gašparík, V. (2014) Školské počítačové meracie systémy vo vyučovaní chémie na základnej škole. Biológia, ekológia, chémia, 18(4), 48-53.

George, A. V., Read, J. R., Barrie, S. C., Bucat, R. B., Buntine, M. A., Crisp, G. T., Jamie, I. M., \& Kable, S. H. (2009). What makes a good laboratory learning exercise? Student feedback from the ACELL project. In

M. Gupta-Bhowon, S. Jhaumeer-Laulloo, H. Li Kam Wah, \& P. Ramasami (Eds.), Chemistry Education in the ICT Age (pp. 363-376). Springer. https://doi.org/10.1007/978-1-4020-9732-4_34

Gilbert, J. K., \& Treagust, D. (2009). Multiple representations in chemical education. Springer.

Haksiz, M. (2014). Investigation of tablet computer use in special education teachers' courses. Procedia - Social and Behavioral Sciences, 141, 1392-1399. https://doi.org/10.1016/j.sbspro.2014.05.240 
Hedlington, L., White, H., \& Curtis, S. (2019). "I cannot live without my [tablet]": Children's experiences of using tablet technology within the home. Computers in Human Behavior, 94, 19-24.

https://doi.org/10.1016/j.chb.2018.12.043

Held, L., Žoldošová, K., Orolínová, M., Juricová, I., \& Kotuláková, K. (2011). Výskumne ladená koncepcia prírodovedného vzdelávania (IBSE v slovenskom kontexte). Typi Universitatis Tyrnaviensis.

Hofstein, A. (2004). The laboratory in chemistry education: Thirty years of experience with developments, implementation and research. Chemistry Education Research and Practice, 5(3), 247-264.

https://doi.org/10.1039/B4RP90027H

Horváthová, E. (2018). Počítačom podporované experimenty s dotykovými koncovými zariadeniami [Diplomová práca]. FPV UMB.

Ješková, Z. (2004) Počítačom podporované experimenty z termiky a termodynamiky v prostredí IP COACH. Univerzita Pavla Jozefa Šafárika.

Johnstone, A. H. (2010). You can't get there from here! Journal of Chemical Education, 87(1), 22-29.

https://doi.org/10.1021/ed800026d

Kovalchick, A., \& Dawson, K. (2004). Education \& technology. An encyclopedia. ABC Clio.

Lavonen, J., Aksela, M., Juuti, K., \& Meisalo, V. (2003). Designing user-friendly datalogging for chemical education through factor analysis of teacher evaluations. International Journal of Science Education, 25(12), 1471-1487. https://doi.org/10.1080/0950069032000072755

Linn, M. C., \& Eylon, B. (2011). Science learning and instruction. Taking advantage of technology to promote knowledge integration. Routledge.

Linn, M. C., \& Hsi, S. (2000). Computers, teachers, peers: Science learning partners. Routledge.

Linn, M. C., Layman, J. W., \& Nachmias, R. (1987). Cognitive consequences of microcomputer-based laboratories: Graphing skills development. Contemporary Educational Psychology, 12(3), 244-253. https://doi.org/10.1016/S0361-476X(87)80029-2

Linn, M. C., \& Songer, N. B. (1991). Teaching thermodynamics to middle school students: What are appropriate cognitive demands? Journal of Research in Science Teaching, 28(10), 885-918. https://doi.org/10.1002/tea.3660281003

Liu, Ch., Wu, Ch., Wong, W., Lien, Y., \& Chao, T. (2017). Scientific modeling with mobile devices in high school physics labs. Computers \& Education, 105, 44-56. https://doi.org/10.1016/j.compedu.2016.11.004

Mamlok-Naaman, R., Eilks, I., Bodner, G., \& Hofstein, A. (2018). Professional development of chemistry teacher. Theory and practice. The Royal Society of Chemistry.

Mang, C., Brown, N., \& Piper, L. (2017). "Old school" meets "new school": Using books and tablets to improve information literacy and promote integrative learning among business students. The International Journal of Management Education, 15, 449-455. https://doi.org/10.1016/j.ijme.2017.07.003

Mann, H. B., \& Whitney, D. R. (1947). On a test of whether one of two random variables is stochastically larger than the other. The Annals of Mathematical Statistics, 18(1), 50-60.

Marcum-Dietrich, N. I., \& Ford, D. J. (2002). The Place for the computer is in the laboratory: An investigation of the effect of computer probeware on student learning. Journal of Computers in Mathematics and Science Teaching, 21(4), 361-379.

Metcalf, S. J., \& Tinker, R.F. (2004). Probeware and handhelds in elementary and middle school science. Journal of Science Education and Technology, 13(1), 43-49. https://doi.org/10.1023/B:JOST.0000019637.22473.02

Mokros, J. R., \& Tinker, R.F. (1987). The impact of microcomputer-based labs on children's ability to interpret graphs. Journal of Research in Science Teaching, 24(4), 369-383. https://doi.org/10.1002/tea.3660240408

Montrieux, H., Vanderlinde, R., Courtois, C., Schellens, T., \& Marez, L. (2014). A qualitative study about the implementation of tablet computers in secondary education: The teachers' role in this process. Procedia - Social and Behavioral Sciences, 112, 481-488. https://doi.org/10.1016/j.sbspro.2014.01.1192

Nachmias, R., \& Linn, M. (1987). Evaluations of science laboratory data: The role of computer-presented information. Journal of Research in Science Teaching, 24(5), 491-506. https://doi.org/10.1002/tea.3660240509

Oliemat, E., Ihmeideh, F., \& Alkhawaldeh, M. (2018). The use of touch-screen tablets in early childhood: Children's knowledge, skills, and attitudes towards tablet technology. Children and Youth Services Review, 88, 591-597. https://doi.org/10.1016/j.childyouth.2018.03.028

Pierri, E., Karatrantou, A., \& Panagiotakopoulos, C. (2008). Exploring the phenomenon of change of phase of pure substances using the microcomputer-based-laboratory (MBL) system. Chemistry Education Research and Practice, 9(3), 234-239. https://doi.org/10.1039/B812412B 
Priest, S. J., Pyke, S. M., \& Williamson, N. M. (2014). Student perceptions of chemistry experiments with different technological interfaces: A comparative study. Journal of Chemical Education, 91(11), 1787-1795. https://doi.org/10.1021/ed400835h

Rane, L. (2013). The effectiveness of MBL experiments in developing conceptual understanding in kinematics among undergraduate physics students. In T. Bastiaens, \& G. Marks (Eds.), World Conference on E-Learning in Corporate, Government, Healthcare, and Higher Education (Las Vegas) (pp. 2495-2502). San Diego, USA, Association for the Advancement of Computing in Education (AACE).

Redish, E. F., Saul, J. M., \& Steinberg, R. N. (1997). On the effectiveness of active-engagement microcomputer-based laboratories. American Journal of Physics, 65(1), 45-54. https://doi.org/10.1119/1.18498

Reychav, I., \& Wu, D. (2015). Mobile collaborative learning: The role of individual learning in groups through text and video content delivery in tablets. Computers in Human Behavior, 50, 520-534.

https://doi.org/10.1016/j.chb.2015.04.019

Rideout, V. (2013). Zero to eight. Children's media use in America. Report of Common sense media's program for the study of children and media. Common Sence Media.

https://www.commonsensemedia.org/file/zerotoeightfinal2011pdf-0/download

Rogers, L. T. (1995). Computer as an aid for exploring graphs. School Science Review, 76(276), 31-39.

Rosenthal, R. (1991). Meta-analytic procedures for social research. 2nd ed. CA.

Russell, D. W., Lucas, K. B., \& McRobbie, C. J. (2003). The role of the microcomputer-based laboratory display in supporting the construction of new understandings in kinematics. Research in Science Education, 33(2), 217-243. https://doi.org/10.1002/tea.10129

Ryan, R. M., \& Deci, E. L. (2000). Intrinsic and extrinsic motivations: Classic definitions and new directions. Contemporary Educational Psychology, 25(1), 54-67. https://doi.org/10.1006/ceps.1999.1020

Sassi, E., Monroy, G., \& Testa, I. (2005). Teacher training about real-time approaches: Research-based guidelines and training materials. Science Education, 89(1), 28-37. https://doi.org/10.1002/sce.20041

Schauer, F., Lustig, F., Dvořák, J., \& Ožvoldová, M. (2008). An easy-to-build remote laboratory with data transfer using the Internet School Experimental System. European Journal of Physics, 29(4), 753-766. https://doi.org/10.1088/0143-0807/29/4/010

Shuler, C., Winters, N., \& West, M. (2013). The future of mobile learning: Implications for policy makers and planners. UNESCO working paper series on mobile learning. UNESCO.

https://unesdoc.unesco.org/ark:/48223/pf0000219637

Simsek, M., \& Dogru, I. A. (2014). Tablet Pc based clasroom. Procedia - Social and Behavioral Sciences, 116, 4246-4249. https://doi.org/10.1016/j.sbspro.2014.01.925

Skoršepa, M. (2012). Ako „uhasit“" pálenie záhy - príklad školského chemického experimentu s podporou výpočtovej techniky. Biológia, ekológia, chémia, 16(3-4), 8-11.

Skoršepa, M. (2014). Stomach acid and antacids. Project No. 517587-LLP-1-2011-1-ES-COMENIUS-CMP. [online] http://comblab.uab.cat/

Skoršepa, M. (2015). Počítačom podporované experimenty v prírodovednom vzdelávaní. Belianum (Vydavatelstvo UMB).

Skoršepa, M., \& Melicherčík, M. (2001). Zaujímavé kontinuálne merania z chémie uskutočňované SM Systémom. In Proceedings of II. Conference for Ph.D. students (pp. 254-258). Nitra, FPV UKF.

Skoršepa, M., Stratilová Urválková, E., Šmejkal, P., Tortosa Moreno, M., \& Urban-Woldron, H. (2014). Activities with sensors in laboratory of biology: Students' motivation and understanding the results. In M. Nodzyńska, P. Cieśla, \& A. Kania (Eds.), Experiments in teaching and learning natural sciences (pp. 25-33). Pedagogical University of Krakow.

Skoršepa, M., \& Šmejkal, P. (2018). Comprehending Computer Based Laboratory Activities by Slovak and Czech Students. In P. Ciesla, \& A. Michniewska (Eds.), Science Teaching in the XXI Century (pp. 72-82). Pedagogical University of Krakow.

Skoršepa, M., \& Tortosa Moreno, M. (2014). Faktory ovplyvňujúce motivačnú orientáciu žiakov v počítačom podporovanom laboratóriu. Acta Universitatis Matthiae Belii, ser. chem., 15, 84-91.

SPSS INC. PASW Statistics for Windows. (2009). Ver. 18.0. SPSS Inc., Ed. 2009.

Stein, J.S. (1987). The computer as lab partner: Classroom experience gleaned from one year of Microcomputer-Based Laboratory use. Journal of Educational Technology Systems, 15(3), 225-236. https://doi.org/10.2190/12PK-CDVR-EGP4-XDLW 
Svec, M. (1999). Improving graphing intrepretation skills and understanding of motion using microcomputer based laboratories. Electronic Journal of Science Education, 3(4).

Šmejkal, P., \& Stratilová Urválková, E. (2011). Školní měřicí systémy pro výuku chemie - mají o ně žáci vůbec zájem? In M. Ulrich, \& K. Zatloukal (Eds.), Alternativni metody výuky 2011, 9. ročník mezinárodní konference (s. 1-9). Gaudeamus.

Šmejkal, P., \& Stratilová Urválková, E. (2012). Support for use of probeware in science for teachers and pupils. In P. Ciesla et al. (Eds.), Chemistry Education in the Light of the Research (pp. 118-123). Pedagogical University of Krakow.

Testa, I., Monroy, G., \& Sassi, E. (2002). Students' reading images in kinematics: the case of real-time graphs. International Journal of Science Education, 24(3), 235-256. https://doi.org/10.1080/09500690110078897

Tho, S. W., \& Hussain, B. (2011). The development of a microcomputer-based laboratory (MBL) system for gas pressure law experiment via open source software. International Journal of Education E Development using Information $\& 5$ Communication Technology, 7(1), 42-55.

Thornton, R. K. (1991). Using the microcomputer-based laboratory to improve student conceptual understanding in physics. Turkish Journal of Physics, 15(2), 316-335.

Thornton, R. K., \& Sokoloff, D. R. (1990). Learning motion concepts using real-time microcomputer-based laboratory tools. American Journal of Physics, 58(9), 858-867. https://doi.org/10.1119/1.16350

Tinker, R.F. (1984). Microcomputers in the lab: Techniques and applications. Technical Educational Research Center.

Tinker, R.F. (2000). A history of probeware. The Concord Consortium. [online] https://concord.org/sites/default/files/pdf/probeware_history.pdf

Tolvanen, S. (2012, nepublikované). Could oceans save us from climate change? Project No. 517587-LLP-1-2011-1-ES-COMENIUS-CMP.

Tortosa Moreno, M. (2012). The use of microcomputer based laboratories in chemistry secondary education: Present state of the art and ideas for research-based practice. Chemistry Education Research and Practice, 13(3), 161-171. https://doi.org/10.1039/C2RP00019A

Tortosa Moreno, M., Skoršepa, M., Guitart Mas, J., Urban-Woldron, H., Aksela, M. K., Tolvanen, S., Stratilová Urválková, E., \& Śmejkal, P. (2013). Design of research-based lab sheets for the acquisition of science competencies using ICT real-time experiments. Do students get the point of what they are doing? In C. P. Constantinou, N. Papadouris, \& A. Hadjigeorgiu, E-Book Proceedings of the ESERA 2013 Conference "Science Education Research For Evidence-based Teaching and Coherence in Learning", Strand 4. (pp. 695-703). Nicosia, Cyprus, European Science Education Research Association.

Trumper, R., \& Gelbman, M. A. (2001). Microcomputer-Based Contribution to Scientific and Technological Literacy. Journal of Science Education and Technology, 10(3), 213-221.

https://doi.org/10.1023/A:1016673931746

Urban-Woldron, H., Tortosa Moreno, M., \& Skoršepa, M. (2013). Implementing learning with sensors in science education: Students' motivational orientations toward using MBL. In In C. P. Constantinou, N. Papadouris, \& A. Hadjigeorgiu (Eds.), E-Book Proceedings of the ESERA 2013 Conference "Science education research for evidence-based teaching and coherence in learning", Strand 4. (pp. 848-854). Nicosia, Cyprus, European Science Education Research Association.

Vernier Software \& Technology. (2019). Company website (homepage). https://www.vernier.com/

Volk, M., Cotič, M., Zajc, M., \& Starcic, A. I. (2017). Tablet-based cross-curricular maths vs. traditional maths classroom practice for higher-order learning outcomes. Computers $\&$ Education, 114, 1-23. https://doi.org/10.1016/j.compedu.2017.06.004

Voogt, J., Tilya, F., \& Akker, J. (2009). Science teacher learning of MBL-supported student-centered science education in the context of secondary education in Tanzania. Journal of Science Education and Technology, 18(5), 429-438. https://doi.org/10.1007/s10956-009-9160-8

Ward, N. D., Finley, R. J., Keil, R. G., \& Clay, T. G. (2013). Benefits and limitations of iPads in the high school science classroom and a trophic cascade lesson plan. Journal of Geoscience Education, 61(4), 378-384.

White, R. T., \& Gunstone, R. F. (1992). Probing understanding. Routledge.

Yang, X., Li, X., \& Lu, T. (2015). Using mobile phones in college classroom settings: Effects of presentation mode and interest on concentration and achievement. Computers ES Education, 88, 292-302. https://doi.org/10.1016/j.compedu.2015.06.007 
Yeung, A., Pyke, S. M., Sharma, M. D., Barrie, S., Buntine, M. A., Burke da Silva, K., Kable, S. H., \& Lim, K. F. (2011). The advancing science by enhancing learning in the laboratory (ASELL) project: The first Australian multidisciplinary workshop. International Journal of Innovation in Science and Mathematics, 19(2), 51-72.

Zelenický, L., Valovičová, L., Jenisová, Z., \& Štubňa, M. (2011). Počítačom podporované experimenty. UKF.

Zydney, J. M., \& Warner, Z. (2016). Mobile apps for science learning: Review of research. Computers

E Education, 94, 1-17. https://doi.org/10.1016/j.compedu.2015.11.001 